\author{
Denis Fedun \\ Department of Psychology, Pedagogy and Philosophy \\ Kremenchuk National University, Kremenchuk, Ukraine \\ E-mail: carre.fd@gmail.com \\ ORCID: https://orcid.org/0000-0003-0530-8285
}

\title{
Training of economic personnel in a university of Ukraine (1960s-1980s of the twentieth century)
}

\begin{abstract}
This article provides general information about the process of economists training in Ukraine during the period with the planned system of economic relations. The main subject of the research is the educational process of training future economists in institutions of higher education in Ukraine in the 1960s-1980s of the twentieth century. The structural constituent elements of the educational process are considered on the example of Kiev Institute of National Economy and Kharkov Engineering and Economic Institute. The purpose of the article is to study and analyze the pedagogical experience of economic personnel training for the planned system of regulation of financial and economic relations and to identify promising areas for further research, with the subsequent introduction of the identified progressive historical experience into the modern system of higher economic education. In the process of studying the history of economic personnel training in higher educational institutions of Ukraine, in the 1960s-1980s, on the basis of such methodological principles as: scientificness, objectivity and historicism (including the use of chronological scientific and systematic approaches), it was applied a theoretical-search research method: historical analysis of literature, documents and archival materials. The article includes: the study of the duration of the learning process; training schedule for specialists; allocation of training time for laboratory work, workshops, seminars, lectures. Within the boundaries of the main subject of the study, educational subjects of general scientific, general economic, general technical and specialized cycles are also presented, which are included in the plan of the educational process. The optional disciplines recommended for study at the student's choice are considered. Practical training is highlighted as a rather important element in the training of an economist. Options for end-of-course assessments are presented. Also, in the process of studying the historical experience of economists training in the higher education system of Ukraine, the following structural elements were analyzed: the system of higher educational institutions, through which the training of economists was carried out; forms of specialists training; types of training sessions used in the learning process; the applied knowledge assessment system; existing qualification areas of training, which included a variety of economic specialties. The value of this study lies in the fact that the pedagogical experience of the process of economists training in the period with the planned economic model of management in the Ukrainian higher education institution in the 60s-80s of the twentieth century was studied for the first time. The result of the research is the obtained data on the training of economists for a system with a planned type of regulation of economic processes, as well as the formed directions for deeper research. The main directions recommended for further detailed study in the preparation of economists with knowledge of planned methods of economic regulation are studying of: directions of specialists training and their relevance today; knowledge assessment and control system; analysis of curricula and time budget, identification of the relationship between theoretical and practical training; practice of independent and research activities, options for final certification.
\end{abstract}

DOI: https://doi.org/10.30525/2500-946X/2021-2-17

\section{Introduction}

Today, many economies of the world, being on their way to world economic globalization, are faced with such fundamental problems as: existence in the conditions of applied trade restrictions and economic sanctions; the likelihood of military conflicts; the increased number of environmental disasters associated with man-made human activities; the use of non-renewable natural resources of the Earth; global warming; the accelerating growth of the

\section{Keywords}

Pedagogical experience, planned economy, training of economists, system of higher economic education, educational process, economist

JEL: I23 
on the development of market models of management, did not pay enough attention to the training of specialists with theoretical knowledge and practical skills of planned regulation of economic processes.

Today, the need for the training of universal, highly qualified personnel who can work both at the microeconomic level in the mode of market relations and at the macroeconomic level under the conditions of planned regulation is quite urgent. And at the same time, such personnel must have at least theoretical skills in economic activity in closed (self-sufficient) economic systems.

The study of the system of training economists in Ukraine during the 60 s-80s of the twentieth century for the planned model of management will have a positive impact on the introduction of historically proven progressive pedagogical elements into the modern educational system.

For the first time, the task of the study is to study the educational process in higher educational institutions of Ukraine focused on the training of economic personnel in the 1960s-1980s. Additionally, the task was set to determine the individual, most important, elements of the educational process for further, deeper analysis and study.

The material of the article is an overview analysis of historical data presented in the following logical sequence: the system of higher economic educational institutions, forms and types of training, knowledge assessment system, areas of training, educational process, conclusions and recommendations for further research.

\section{The system of higher economic educational institutions of Ukraine}

Higher economic education in Ukraine was carried out through the system of such higher educational institutions as: universities, academies, institutes. By the beginning of the second half of the twentieth century, on the territory of the Ukrainian SSR, the training of economic personnel was carried out by such modern universities as: Lviv University of Trade and Economics (founded in 1816), Kiev National Economic University (1906), Kiev National University of Trade and Economics (1946), Odessa National Economic University (1921), Donetsk National University of Economics and Trade (1920), Kharkiv National Economic University (1893), Poltava University of Economics and Trade (1961), Ternopil National Economic University (1966), Kryvyi Rih Economic Institute (1966) and some others (Fedun, 2021).

\section{Forms and types of educational classes}

According to the Decree of the Council of Ministers of the USSR of January 22, 1969 «On Approval of the Regulation on Higher Educational Institutions of the USSR", the training of economists in the higher education system was carried out in the following two forms: in the classroom (full-time study) and in off-work hours (extra-mural and evening study).

The types of educational classes with the help of which the higher educational institutions of Ukraine in the 1960s-1980s carried out their pedagogical activities were: lectures; consultations; laboratory work, seminars, practical exercises; educational and industrial practice; independent educational activity of students; test papers; course and diploma design (or work).

\section{Knowledge assessment system}

Assessment of academic progress of future economists in the $60 \mathrm{~s}-80$ s of the twentieth century was carried out using a 4-point system for assessing knowledge: «excellent», "good», «satisfactory», «unsatisfactory» (Postanovlenie, 1969). According to the Order of the Ministry of Higher and Secondary Specialized Education of the USSR of June 11,1973 «On the approval of the regulation on course examinations and credits in higher educational institutions of the USSR» according to a 4-point system, knowledge assessment was carried out: in subjects at exams, course projects (works), industrial practice and differentiated tests. Evaluation of disciplines providing for a credit system in the curriculum was carried out according to a 2-level system: «credited» or «not credited» (Prikaz, 1973).

In the examinations, which were held on individual examination papers, both orally and in writing, the examiner had the right to additional questions, including tasks for the program of a particular course. To obtain certification for course projects, it was necessary to defend them in front of his supervisor and a special commission (Prikaz, 1973).

Assessment of knowledge for courses providing for a system of "credits» was carried out before the start of the examination session. Seminars were credited basing on the actual writing of reports and abstracts. Certain disciplines could be credited upon completion of tests in practical classes. Laboratory and practical work was counted immediately as they were completed and defended, throughout the semester. The social science credits were assessed using a survey method. A credit for educational practice could be obtained on the basis of a report on its completion, and already a credit for industrial practice was affixed solely on the basis of the defense of the report with a special commission, which included: the head of the practice, department staff and, as a rule, representatives of the base of the practice (Prikaz, 1973).

\section{Directions of training}

Various directions of economists training, for the system with a command-planned economic model of regulation that existed in the 60 s-80s of the twentieth century in Ukraine, were fixed by the Order of the Ministry of Higher and Secondary Specialized Education of the USSR dated September 05, 1975 «On Approving the List of Existing Specialties and specializations of higher educational institutions». According to this document, economic universities and individual faculties had the opportunity to train highly qualified specialists in 47 specialties in the «Economics» group:

- The following directions corresponded to the training of specialists with the qualification «Economist»: Planning of the national economy, Planning of industry, Economics and planning of material and technical supply, Economics of labor, Planning of agriculture, Economics and organization of procurement of agricultural products, Economics of trade, Finance and credit, Statistics, Accounting;

- The training of specialists with the qualification «Engineer-economist» was carried out in the following areas: Economics and organization of the mining industry, Economics and organization of the oil and gas industry, Economics and organization of energy, Economics and organization of the metallurgical 
industry, Economics and organization of the machinebuilding industry, Economics and organization of the chemical industry, Economics and organization of the printing industry, Economics and organization of consumer goods industry, Economics and organization of the food industry, Economics and organization of the timber industry and forestry, Economics and organization of the woodworking and pulp and paper industry, Economics and organization of construction, Economics and organization urban economy, Economics and organization of railway transport, Economics and organization of water transport, Economics and organization of road transport, Economics and organization of air transport, Economics and organization of communications, Organization of mechanized processing of economic information, Economics and organization of consumer services, Economics and organization of the radio-electronic industry, Economics and organization of the building materials industry, Economics and organization of water management, Organization of production management in the machine-building industry, Organization of production management in the metallurgical industry, Organization of production management in the chemical industry, Organization of management in construction, Organization of management in urban economy, Organization of management in road transport, Organization of management in the energy sector;

- Training of economists with qualifications corresponding to a rather narrow industry focus: Economist of cinematography and television, Economist-provider of agricultural production, Book expert-provider of book trade, Economist in international relations with knowledge of a foreign language, Commodity expert with higher qualifications (Commodity science and organization of trade in industrial goods, Commodity science and organization of food trade), Agricultural accounting economist (Prikaz, 1975)

\section{Educational process}

The annual educational process, in the evening and full time forms of study, consisted of two semesters, at the end of which an examination session was held. The academic year in the extra-mural tuition course was carried out according to the curriculum, and laboratory examination sessions were conducted in several stages (depending on the specialty, course or specific study group) (Postanovlenie, 1969).

For students studying in the full time or evening forms, the holidays were set by the curriculum twice a year, with a total duration of 7 to 10 weeks. Students taking extra-mural studies were provided with holidays once in each academic year for 8 to 10 weeks. The duration of the holidays and their calendar schedule was determined by the curriculum for a particular specialty (Postanovlenie, 1969).

The educational process in higher economic educational institutions of Ukraine in the 1960s-1980s was carried out according to the approved curricula.

At four faculties of Kiev Institute of National Economy (Industrial Economics, Agricultural Economics, Financial and Economic and Accounting and Statistics), the four-year schedule for specialists training with the qualification of
«Economist» was divided into four-year courses, consisting of two hundred academic weeks. The duration of the 1st-3d courses was 52 weeks, the 4 th took 44 weeks. Courses 1st and 2nd consisted of 35 weeks of theoretical training, 7 weeks of examination sessions and 10 weeks of vacation; The $3 \mathrm{~d}$ course took 32 weeks of theoretical training, 8 weeks of educational practice, 6 weeks of examination sessions, 6 weeks of vacation; The 4th took 13 weeks of theoretical training, 20 weeks of industrial practice, 7 weeks of diploma design or state examination and 1 week of vacation (Uchebnye plany, 1969; Uchebnye plany, 1974).

Kharkov Engineering and Economics Institute (KEEI) at six faculties (Mechanical Engineering, Chemical, Mining, Metallurgical, Evening and Extra-mural) trained specialists with the qualification «Engineer-Economist».

The five-year schedule of the educational process of training in the classroom consisted of five courses, consisting of 251 academic weeks (at the beginning of the 60s of the twentieth century in Ukraine, when training engineerseconomists, for students without two years of work experience at the enterprise, the total training period was 5 , 5 years). The duration of the 1 st -4 th courses was 52 weeks each, and the 5 th -43 weeks. The 1 st- 4 th courses consisted mainly of 29-35 weeks of theoretical training, 6-8 weeks of examination sessions and 6-10 weeks of vacation, also in the 1st-2nd course, in some specialties, 2-4 weeks educational practice was provided, and in the 3d-4th courses from 5 to 15 weeks were allocated for industrial practice; 5 th year 10-15 weeks of theoretical training, from 6 to 26 weeks of industrial practice, 2-3 weeks of examination sessions, 16-18 weeks of graduate design, 2 weeks of vacation (Uchebnye plany, 1960; Uchebnye plany, 1965; Uchebnye plany, 1970; Uchebnye plany, 1984).

The number of hours of training, in all disciplines at Kiev Institute of National Economy (KINE), for the entire period of study, was (depending on the specialty) from 3480 to 3580, of which: lectures - from 1700 to 1920 , laboratory classes - from 30 up to 300 , practical lessons - from 1140 to 1370 and seminars - from 310 to 430 hours. At KEEI, the total number of hours of training was (depending on the specialty) - from 4348 to 4804 , of which: lectures - from 2052 to 2454, laboratory classes from 220 to 670, practical classes - from 1260 to 1830 and seminars - from 300 up to 356 hours (Uchebnye plany, 1969; Uchebnye plany, 1974).

The course of study of an economist in the 1960s-1980s also included the completion of the required number of coursework, obtaining scheduled credits and exams in the subjects studied.

Studying at Kiev Institute of National Economy implied the need to defend four course projects, pass 28 credits and 32 exams. In Kharkov Engineering and Economic Institute, it was required, depending on the chosen specialty, to defend from four to ten term papers (or projects), to pass positively from 38 to 50 credits and from 33 to 41 exams (Uchebnye plany, 1969; Uchebnye plany, 1974).

The curriculum plan for all economic specialties meant training in such cycles of subjects as: general scientific, general economic and specialized. In the process of training in engineering and economic specialties, the cycle of general technical disciplines was also included.

The cycle of disciplines of general scientific training included the study of: History of the CPSU, Marxist-Leninist philosophy, Fundamentals of scientific communism, 
Fundamentals of Soviet law, Foreign language, Higher mathematics, Probability theory and mathematical statistics.

The cycle of subjects of general economic training for most economic specialties included: Political economy, Economic geography of the USSR and foreign countries, Economic history of the USSR and foreign countries, Finance, Accounting, Economic planning, Economics and organization of production, Economics of industry (or agriculture), Theoretical and economic and mathematical statistics, Analysis of economic activity, Mathematical programming, Economic and mathematical methods and models of management, Theory of organization and management of mechanized (automatic) processing of economic information and programming of economic calculations.

The list of disciplines of the general technical direction (necessary for the training of engineers-economists) included: Physics, Inorganic chemistry, Engineering graphics, Fundamentals of electronics and electrical engineering, Technical controls, Computer work and programming, Metallurgy and thermodynamics, Mechanics, Theory of mechanisms and machines, Technologies of the most important industries.

Vocation-related subjects, different for each of the areas, provided the training of the future economist in the chosen specialty.

The economist's training course also included optional elective disciplines, the list of which was approved by the Council of the Institute. The most characteristic optional subjects for this period were: Marxist-Leninist Ethics and Aesthetics, Fundamentals of Scientific Atheism, Civil Defense, Medical Training, History of Economic Studies, Fundamentals of Research, Office Work and Correspondence.

In the early 80 s of the twentieth century, such disciplines of general scientific and general economic training as: Introduction to the specialty, Algorithmization and programming for computers, Special practice on micro and mini computers, Fundamentals of ecological safety and environmental protection, the subject of the study of the world's economies by branches of specialization was also introduced.

Students of economic specialties of the university of Ukraine in the 1960s-1980s, without fail, received professional experience in educational and industrial practices. Students of Kiev Institute of National Economy underwent 8-weeks practical training in the 6th semester and 20-weeks industrial practice in the 8th semester (Uchebnye plany, 1969; Uchebnye plany, 1974). Students of Kharkov Engineering and Economic Institute, depending on the chosen specialty and curriculum, received experience in from 2 to 5 educational and industrial practices, with a total duration of 20 to 34 weeks (Uchebnye plany, 1960; Uchebnye plany, 1965; Uchebnye plany, 1970; Uchebnye plany, 1984).

The training of specialists in the system of higher economic education in Ukraine was completed with the performance and defense of the thesis and/or the passing of the state exam before the State Examination Board (depending on the specialty and year of study). In KEEI the list of examination subjects included: Political Economy; Organization, economics and enterprise planning; as well as a specialized subject. Education at KINE ended exclusively with the defense of the diploma project.

\section{Conclusions}

Higher economic education in Ukraine in the 1960s-1980s was a highly organized educational system, which, thanks to the forms used and the variety of types of educational process, taking into account the economic interests of the planned economic system, prepared multidirectional economists in a fairly large list of specialties with qualifications «Economist», «EngineerEconomist» and some other narrow-branch areas. The higher educational institutions that existed at that time fully and completely satisfied the need of the Ukrainian republic for qualified economic personnel. The theoretical training course was a full-fledged study of general scientific, general economic, vocation-related, optional and general technical disciplines. A fairly large place in the educational process was given to the development of practical skills, which was especially expressed in the training of specialists with the qualification «EngineerEconomist».

In order to introduce into the modern system of economic education the progressive elements used in the period with the planned system of economic relations, it is recommended to study in more depth and in detail the following elements identified in this study:

- areas of training of specialists and their potential relevance in the realities of modern economic relations;

- assessment system and practice of measuring knowledge;

- curricula;

- time budget of the educational process;

- the relationship between theoretical training and practical skills;

- practice of independent work and research activities of students;

- options for final certification.

The study of the training methodology and the introduction into the educational process, first of all, of engineering and economic specialties, the need for which is extremely relevant today for industrial, mining, processing and other industrial sectors of the Ukrainian economy, will contribute to improving the quality and competitiveness of Ukrainian products in the domestic and world markets, optimization of production costs. Also, a detailed study of this direction will help improve the training of specialists who have the skills to work in conditions with planned methods of economic regulation for the application, both when planning and managing macroeconomic processes, and using them in periods with various economic constraints.

\section{References}

[1] Fedun, D. S. (2021). Rozvytok profesiinoi pidhotovky ekonomistiv u systemi vyshchoi osvity Ukrainy (druha polovyna XX - pochatok XXI st.) [Development of economists professional training in the system of higher education of Ukraine (second half of XX - beginning of XXI century)]. Aktualni pytannia humanitarnykh nauk: mizhvuzivskyi zbirnyk naukovykh prats molodykh vchenykh Drohobytskoho derzhavnoho pedahohichnoho universytetu imeni Ivana Franka, Topical issues of 
EDUCATION Economics \& Education 2021 06(02) August 99 the humanities: an intercollegiate collection of researchers working with young people with Drohobych workers at Ivan Franko University, 35(3), 229-237. (in Ukrainian)

[2] Postanovlenie Soveta Ministrov SSSR № 64 ot 22.01 .1969 goda «Ob utverzhdenii polozheniya o vysshih uchebnyh zavedeniyah SSSR» (1969) [Resolution of the Council of Ministers of the USSR No. 64 of 01/22/1969 "On the approval of the regulations on higher educational institutions of the USSR»]. economics.kiev.ua. E-source: http://economics.kiev.ua/download/ZakonySSSR/data03/tex15196.htm (in Russian)

[3] Prikaz Ministerstva vysshego i srednego specialnogo obrazovaniya SSSR № 513 ot 11.06.1973 goda «Ob utverzhdenii polozheniya o kursovyh ekzamenah i zachetah v vysshih uchebnyh zavedeniyah SSSR» (1973) [Order of the Ministry of Higher and Secondary Specialized Education of the USSR No. 513 of 06/11/1973 «On approval of the regulations on course examinations and tests in higher educational institutions of the USSR»]. economics.kiev.ua. E-source: http://www.economics.kiev.ua/download/ZakonySSSR/data03/tex14657.htm (in Russian)

[4] Prikaz Ministerstva vysshego i srednego obrazovaniya SSSR № 831 ot 05.09.1975 goda «Ob utverzhdenii perechnya dejstvuyushih specialnostej i specializacij vysshih uchebnyh zavedenij» (1975) [Order of the Ministry of Higher and Secondary Education of the USSR No. 831 of 09/05/1975 «On approval of the list of existing specialties and specializations of higher educational institutions»]. libussr.ru. E-source: http://www.libussr.ru/doc_ussr/ usr_8718.htm (in Russian)

[5] Uchebnye plany po specialnostyam $1701,1702,1703,1704,1716,1736,1737,1738,1740$ stacionarnogo obucheniya na 1969/1970 uchebnyj god (1969) [Curricula for the specialties 1701, 1702, 1703, 1704, 1716, 1736, 1737, 1738, 1740 of stationary education for the 1969/1970 academic year]. Derzharkhiv m. Kyieva - State Archives of Kyiv. F. R-871. Op. 20. Spr. 1450. 19 ark. (in Russian)

[6] Uchebnye plany (stacionarnoe obuchenie) na 1974 uchebnyj god (1974) [Curricula (stationary education) for the 1974 academic year]. Derzharkhiv m. Kyieva - State Archives of Kyiv. F. R-871. Op. 20. Spr. 2162. 4 ark. (in Russian)

[7] Uchebnye plany na 1959-1960 uchebnyj god (1960) [Curricula for the 1959-1960 academic year]. Harkovskij oblastnoj gosudarstvennyj arhiv - Kharkiv Regional State Archives. F. R - 4587. Op. 2. Del. 581. 29 str. (in Russian)

[8] Uchebnye plany na 1964-1965 uchebnyj god (1965) [Curricula for the 1964-1965 academic year]. Harkovskij oblastnoj gosudarstvennyj arhiv - Kharkiv Regional State Archives. F. R - 4587. Op. 2. Del. 848. 26 str. (in Russian)

[9] Uchebnye plany Himicheskogo fakulteta na 1969-1970 uchebnyj god (1970) [Curricula of the Faculty of Chemistry for the 1969-1970 academic year]. Harkovskij oblastnoj gosudarstvennyj arhiv - Kharkiv Regional State Archives. F. R - 4587. Op. 2. Del. 973. 2 str. (in Russian)

[10] Uchebnye plany po specialnostyam vysshego inzhenerno-tehnicheskogo i selskohozyajstvennogo obrazovaniya Soyuza Sovetskih Socialisticheskih Respublik, utverzhdennye Ministerstvom vysshego i srednego specialnogo obrazovaniya SSSR v 1984 godu (1984) [Curricula for the specialties of higher engineering, technical and agricultural education of the Union of Soviet Socialist Republics, approved by the Ministry of Higher and Secondary Specialized Education of the USSR in 1984]. Portal Federalnyh gosudarstvennyh obrazovatelnyh standartov vysshego obrazovaniya - Portal of Federal State Educational Standards of Higher Education. E-source: http://fgosvo.ru/support/154/154/46 (in Russian) 